\title{
Gene therapy pushes on, despite doubts
}

[WASHINGTON] A conference on in utero gene therapy organized by the US National Institutes of Health (NIH) concluded last week that many significant scientific and ethical questions must be answered before the practice can or should be attempted in humans.

But despite the obstacles - and determined opposition from activists who attended - senior NIH officials said they would continue to revise their guidelines on gene therapy to address eventual in utero applications. The revisions could be published as soon as June.

The Food and Drug Administration (FDA), which holds the final power to

approve in utero protocols, also appeared keen to push ahead. "We need to make sure that whatever we do, the very best technology is used," Philip Noguchi, director of the FDA's Division of Cellular and Gene Therapies, told the meeting. "And the only way to get there is to really force the issue."

The technique's immaturity was clear at the meeting. Experts pointed to a dearth of animal data, and to human risks including inadvertent genetic modification of fetal sperm and eggs, or even of the rapidly proliferating breast and uterine tissue of mothers.

Some also warned of children being only partially cured of severe diseases, and posing

\section{Senator seeks reassurance on $\mathrm{NIH}$ budget}

[WASHINGTON] A leading US senator is questioning whether the National Institutes of Health $(\mathrm{NH})$ can effectively spend the $\$ 2$ billion, 15 per cent increase it received in the current fiscal year, and whether it should receive a similarly large boost next year.

Senator Pete Domenici (Republican, New Mexico), the chairman of the Senate Budget Committee, says he may hold an unusual committee hearing in the spring to address the issue. "We want to make sure that the large increases are being used effectively and efficiently, not only for the good of science but for the good of the American taxpayer," Domenici said last week.

Last month, at Domenici's instigation, top Budget Committee staff members led by Bill Hoagland, the committee's chief of staff, met Harold Varmus, the $\mathrm{NH}$ director, and other institute directors. Officials from the Congressional Budget Office and the General Accounting Office also attended.

Discussions centred on how $\mathrm{NHH}$ distributes funds among its institutes, how it sets research priorities, and how it takes public health needs into account in doing so.

"[NH was] popping up on the radar screen as an outlier" because it received

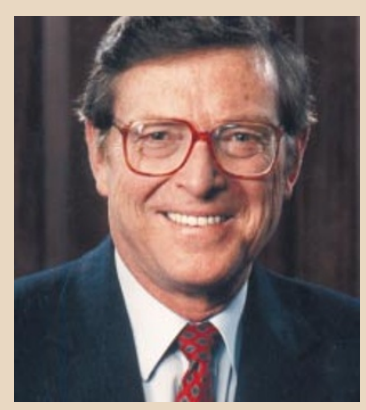

Domenici: are the NIH's extra billions spent efficiently?

the single largest percentage increase of any agency in 1999, says Hoagland. "We wanted to make sure that the dollars were being used effectively."

Varmus argues that the money is being spent wisely. "I see no difficulty in managing this increase, and subsequent increases of similar size," he says. "It's crucial that we work with a steady growth plan."

$\mathrm{He}$ adds that "every institute and centre has a series of very impressive plans" for handling the new money, which is funding "everything from over 1600 new research project grants to the sequencing of the mouse genome."

Yesterday (13 January), Hoagland and other Budget Committee staff were scheduled to meet again with Francine Little, the director of NHI's Office of Financial Management. They planned to discuss whether it is using its $\$ 15.58$ billion budget for fiscal year 1999, efficiently, or whether the \$2 billion of new funds is presenting a money management problem.

Hoagland says he wants to know "what plans they have for how they're going to use these monies. Or are they going to be faced with a situation where they cannot manage the resources in a way that is most efficient? In that case I would suggest they are getting too much."

This is strenuously denied by Varmus, who says that "casual" comments that the $\mathrm{NH}$ might be unable to handle the new money are "very damaging to the research enterprise." Varmus adds: "We have no trouble at all in managing the 1999 increase, giving it very careful attention and accounting for every penny." He says he is sure that Hoagland will agree after looking at the evidence.

Separately, unnamed biomedical research lobbyists last week protested at what they say will be a 2.1 per cent, \$328 million increase for the $\mathrm{NHH}$ in the White House's proposed budget for the year 2000, due to be released in the first week of February. The research community wants an increase closer to the 15 per cent of 1999. Last year, the Clinton administration asked for 8.4 per cent. $\mathbf{M . w}$. formidable, lifelong costs to their families and the healthcare system. And others pointed out that, even in adults, gene therapy has not succeeded.

"I don't know how we can talk about selling it in utero," said Mitchell Globus, professor emeritus of obstetrics and paediatrics at the University of California, San Francisco, and the director of scientific and clinical affairs for Applied Imaging Corp. "We don't have a product to sell post-natally yet."

Despite this, many of those present agreed that the impetus to attempt therapy, despite the risks, is compelling for severe diseases that kill before or shortly after birth, and for seriously disabling diseases with no adequate treatments.

"There is a consensus that in utero gene therapy will have a definitive role to play in a small set of diseases," said French Anderson, professor of biochemistry and paediatrics at the University of Southern California, and a leading pioneer of human gene therapy.

While some at the two-day conference complained of the lack of animal data, there were also signs of progress with animal experiments. Janet Larson, for instance, a neonatologist and staff scientist at the Alton Ochsner Medical Foundation in New Orleans, Louisana, described the successful treatment of cystic fibrosis in knockout mice with in utero therapy.

Meanwhile, Anderson is preparing human protocols for using in utero gene therapy to treat severe combined immunodeficiency and $\alpha$-thalassaemia. He estimates that they will be ready for submission as soon as three years from now. But he is now modifying the draft proposals after questions were raised by the NIH's Recombinant DNA Advisory Committee last September (see Nature 395, 420; 1998).

Activists at the meeting, led by the Council for Responsible Genetics (CRG), argued that if the US government allows the development of in utero gene transfer to fight disease, the technique will inevitably end up being exploited for eugenic purposes.

Paul Billings of the CRG, a medical geneticist who is chief medical officer at Heart of Texas Veterans Health Care System in Dallas, blamed "genetic hysteria" for the meeting participants' openness to developing in utero techniques.

"The Council for Responsible Genetics questions why we're investing so much time and effort in gene therapy for very rare conditions when prenatal diagnosis, embryo selection and adoption are available," said Billings. $\mathrm{He}$ and others also argued that, by providing therapy to younger and younger fetuses, scientists risk playing into an anti-abortion agenda by giving an earlier definition of the beginning oflife.

Meredith Wadman 